Hochstrasser, K. \& Werle, E. (1967). Hoppe-Seyl. Z. 348, 177.

Holman, G., Lowe, J. S., Morley, J. S. \& Smithers, M. J. (1968). Biochem. biophys. Res. Commun. 33, 140.

Mares-Guia, M. \& Diniz, C. R. (1967). Arch. Biochem. Biophys. 121, 750.

Moriya, H., Kato, A. \& Fukushima, H. (1969). Biochem. Pharmacol. 18, 549.
Nagasawa, S., Takahashi, H., Koida, M., Suzuki, T. \& Schoenmakers, J. G. G. (1968). Biochem. biophys. Res. Commun., 32, 644.

Paskhina, T. S., Zhukova, V. P., Egorova, T. P., Narticova, V. F., Karpova, A. V. \& Guseva, M. V. (1968). Biokhimiya, 83, 745.

Sach, E. \& Thely, M. (1968). C. R. Acad. Sci., Paris, 266, 1200.

\title{
COMMUNICATIONS
}

\section{Purification and Characterization of Bovine Enteroviruses}

By M. D. Johnston, S. J. Martin and J. B. Clements. (Department of Biochemistry, Queen's University, Belfast)

Bovine enteroviruses are widely distributed in the cattle population of Ireland. Recent reports (McFerran, Nelson, McCracken \& Ross, 1969) indicate their economic importance in relation to enteritis.

Serologically distinct bovine enteroviruses have been shown to grow readily in baby-hamster kidney (BHK) cells. This system has been used to grow virus in sufficient quantity for the investigation of their nucleic acid and protein components.

Overnight incubation of virus with monolayers of BHK cells disrupts the cell sheet, releasing over $99 \%$ of the virus formed into the medium. The bulk of the cell debris is removed by centrifugation at 2000 rev./min. Remaining cellular contamination is then removed by differential centrifugation, gel filtration through Sepharose $2 \mathrm{~B}$ and sedimentation in $15-40 \%$ sucrose gradients. The purity of the virus has been demonstrated by double-labelling experiments and detergent treatment. This purification scheme is readily adaptable to large-scale zonal-centrifugation procedures.

The nucleic acid of the viruses has been identified as RNA by labelling with $\left[{ }^{3} \mathrm{H}\right]$ uridine. On sucrose gradients viral RNA sediments at $35 \mathrm{~s}$ relative to $28 \mathrm{~s}$ ribosomal RNA. The base compositions of RNA from several serologically distinct bovine enteroviruses are similar. The viruses have a sedimentation value of $165 \mathrm{~s}$ relative to $80 \mathrm{~s}$ ribosomes extracted from BHK cells. Electronmicroscope studies have shown the virus particles to be spherical with a diameter of $27 \mathrm{~nm}$. Their density is $1.34 \mathrm{~g} . / \mathrm{ml}$. as determined by density of the isopyenic centrifugation in $\mathrm{CsCl}$ gradients run in angle heads (Flamm, Bond \& Burr, 1966).

Work is now in progress to study the capsid proteins of a number of bovine enteroviruses.
We are grateful to the Agricultural Research Council for a grant to support this work.

Flamm, W. G., Bond, H. E. \& Burr, H. E. (1966). Biochim. biophys. Acta, 129, 310.

McFerran, J. B., Nelson, R., McCracken, J. M. \& Ross, J. G. (1969). Nature, Lond., 221, 194.

\section{The Reaction Catalysed by a Partially Purified Nucleoside Triphosphate-Dependent Deoxy- ribonucleic Acid-Breakdown System from Mycobacterium smegmatis}

By F. G. Winder and M. LAvin. (Department of Biochemistry, Trinity College, Dublin, Irish Republic)

Streptomycin-treated extracts of Mycobacterium smegmatis that had been grown for $72 \mathrm{hr}$. in ironlimited medium were prepared as described by Winder \& Coughlan (1969). Protamine sulphate $(0 \cdot 1 \%)$ was added, and the precipitate was dissolved in $0.1 \mathrm{M}$-phosphate buffer, $\mathrm{pH} 7 \cdot 5$, containing $1 \mathrm{mM}$ dithiothreitol, concentrated on a Diaflo UM-10 ultrafilter, transferred to a column of Sephadex G-200 and eluted with 0.1 M-phosphate buffer, pH 8.0, containing $1 \mathrm{~mm}$-dithiothreitol. The enzyme was eluted immediately after the void volume, with a 15-20-fold increase in specific activity over the crude extract. Attempts at further purification were unsuccessful owing to low stability.

Incubation mixtures contained usually $0.2 \mathrm{ml}$. of enzyme, $0.4 \mathrm{ml}$. of the latter buffer, $1 \mathrm{mg}$. of the sodium salt of DNA, $2 \mu$ moles of ATP and $20 \mu$ moles of $\mathrm{MgCl}_{2}$ in a total volume of $1 \mathrm{ml}$., or was appropriately scaled up. It was incubated at $37^{\circ}$, usually for $30 \mathrm{~min}$. Assays were as described by Winder \& Coughlan (1969).

The enzyme strongly preferred native to heatdenatured DNA. However, it could degrade more than half of the DNA, probably as the result of a slow attack on single-stranded DNA. The kinetics of loss of viscosity of the DNA and of appearance of acid-soluble deoxyribose were similar, and extraction of DNA remaining after a period of 
reaction, with phenol-sodium dodecyl sulphate (pH9), and its comparison with the starting material by sedimentation in a sucrose gradient showed that species of all molecular weights were diminished similiarly in amount. These facts indicate that enzymic attack was at, or near, the ends of chains.

The acid-soluble products of the reaction were fractionated on a column of Sephadex G-25. The smaller-molecular-weight fraction was chromatographed on Dowex 1 (Miura \& Hayashi, 1967) and the larger-molecular-weight material on Sephadex G-50 in 8M-urea (Stanley, 1967). The results indicated that the DNA was converted into a mixture of mononucleotides and short-chain oligonucleotides. ATP was converted into ADP, and orthophosphate was released in approximately equivalent amount. Substantially more than 1 mole of ATP was used/mole of deoxyribonucleotide solubilized, but residual adenosine triphosphatase activity in some of the enzyme preparations resulted in uncertainty about the stoicheiometry.

This work was supported by grants from the Medical Research Council of Ireland and Shell International Petroleum Company Ltd. M.L. received a maintenance grant from the Department of Education, Irish Republic.

Miura, K. \& Hayashi, Y. (1967). In Methods in Enzymology, vol. 12A, p. 390 . Ed. by Grossman, L. \& Moldave, K. New York: Academic Press Inc.

Stanley, W. M., jun. (1967). In Methods in Enzymology, vol. 12A, p. 404 . Ed. by Grossman, L. \& Moldave, K. New York: Academic Press Inc.

Winder, F. G. \& Coughlan, M. P. (1969). Biochem. J. 111, 679.

\section{Fractionation of Deoxyribonucleic Acid from Multiple-Drug-Resistant Staphylococci on Poly-L-Lysine-Kieselguhr Columns}

By M. Monaghan-Cannon and L. K. Dunican. (Department of Microbiology, University College, Galway, Irish Republic)

DNA has been fractionated by a variety of methods: hydroxyapatite columns (Tiselius, Hjerten \& Levin, 1956; Miyazawa \& Thomas, 1965), methylated albumin on kieselguhr (Mandell \& Hershey, 1960; Roger, Beckmann \& Hotchkiss, 1966 ; Ayad, Barker \& Weigold, 1968), benzoylatednapthoylated DEAE-cellulose (Sedat, Kelly \& Sinsheimer, 1967) and silk-fibroin columns (Huh \& Helleimer, 1967). Fractionation of DNA on polyL-lysine-kieselguhr columns has been reported by Ayad \& Blamire (1968). These authors conclude that the main basis for fractionation on poly-Llysine-kieselguhr columns is base composition, since sonication and the consequent decrease of molecular weight did not affect the elution profile.
Heat denaturation, which disrupts the secondary structure of the DNA, also gave the same elution profile as that of native DNA. The dependence of resolution on base composition is unlike various other fractionation techniques recently reported, which depend on either molecular weight or hydrogen-bonding properties or both.

Staphylococcal DNA was resolved into several fractions by means of poly-L-lysine-kieselguhr columns. The DNA was eluted with a linear gradient of saline phosphate buffer. DNA was extracted from Staphylococcus aureus organisms that were multiple-drug-resistant and from their sensitive variants. The continuous elution profiles of the DNA from these organisms show a considerable degree of diversity, the most important feature being the absence of certain fractions of DNA from the antibiotic-sensitive variants. Present indications are that the DNA in the missing fractions is correlated with the absence of episomal DNA in the variants of the organisms that have lost their resistance to antibiotics. Support for this was found by comparing the DNA fractions from Staphylococcus aureus PS47 and a lysogenized variant of this strain that was resistant to tetracycline (strain $47^{\prime} B$ ). An extra peak in this strain accompanied lysogenization.

Our findings suggest that this technique is valuable in the study of extrachromosomal DNA of staphylococci.

Acknowledgement is made to the Department of Education for a Studentship (M.M.C.) and to an Foras Taluntais for support.

Ayad, S. R., Barker, G. R. \& Weigold, J. (1968). Biochem. J $107,387$.

Ayad, S. R. \& Blamire, J. (1968). Biochem. biophys. Res. Commun. 30, 207.

Huh, T. Y. \& Helleimer, C. W. (1967). Analyt. Biochem. $19,150$.

Mandell, J. D. \& Hershey, A. D. (1960). Analyt. Biochem. 1, 66.

Miyazawa, Y.\& Thomas, C. A. (1965). J. molec. Biol.11, 223.

Roger, M., Beckmann, C. O. \& Hotchkiss, R. D. (1966). J. molec. Biol. 18, 156.

Sedat, J. W., Kelly, R. B. \& Sinsheimer, R. L. (1967). J. molec. Biol. 26, 537.

Tiselius, A., Hjerten, S. \& Levin, O. (1956). Arch. Biochem. Biophys. 65, 132. 